Dr hab. Maciej Perkowski, prof. UwB*

\title{
KONCEPCJA ,NON-STATE ACTORS” A UMIĘDZYNARODOWIENIE REGIONÓW
}

Badania naukowe podmiotowości prawa międzynarodowego skłaniają do postawienia pytania, czy jej stan w pierwszej dekadzie XXI wieku to swoista akceleracja czy może chaos? Rzeczywistość tak bardzo postępuje, że coraz trudniej ją „ogarnąć" nie tylko umysłom przeciętnym, ale i najwybitniejszym. W tym rozpędzonym świecie ludzkość, gorączkowo poszukując pewnego układu odniesienia w większości (paradygmat demokratyczny) spogląda na pieniądz (a to już paradygmat ekonomiczny) i przez ten pryzmat postrzega otaczającą ją rzeczywistość... Niestety, wobec pieniądza zawodzi homocentryzm i z dylematu „być czy mieć” człowiek coraz częściej wybiera „mieć”... Tak rozumując, w namnażaniu prawa ludzkość upatruje jego rozwoju, a nowe sytuacje - zamiast skłaniać ją do refleksji i koncepcyjnej kreatywności - przynoszą na ogół kolejne ,,lex superspecialis”... W konsekwencji takie „wehikuły”, jak podmiotowość, jawią się kształtowanej kazusami „nowej fali” jurystów niewiele znaczącymi uogólnieniami teorii. Tej ostatniej nic zaś nie szkodzi bardziej niż obojętność praktyki. Problem ma jednak „drugie dno”, gdyż teorię z praktyką łączy więź nierozerwalna! Dopóki więc istnieje prawo międzynarodowe dopóty istnieć będzie jego podmiotowość! Nie wątpiąc w istnienie prawa międzynarodowego łatwo jednak zauważyć, że jego podstawowa formuła odstaje od współczesnej rzeczywistości, a rozmaite koncepcje enigmatyczne, które jeszcze niedawno funkcjonowały obok (lub w cieniu) tych klasycznych, dziś zdają się je przysłaniać... Skoro współczesne prawo międzynarodowe jest inne niż jego klasyczna, a nawet ta z Karty Narodów Zjednoczonych postać, inna też jest jego podmiotowość. ${ }^{145}$ Warto zatem rozważać jej rozwój, także w wariantach kontrowersyjnych, jak ten zawarty w tytule niniejszego opracowania.

We współczesnej doktrynie prawa międzynarodowego dużą popularność zyskała koncepcja aktorów pozapaństwowych, częściej określanych według angloję-

Kierownik Zakładu Prawa Międzynarodowego Publicznego na Wydziale Prawa Uniwersytetu w Białymstoku; radny Sejmiku Województwa Podlaskiego.

145 Por.: L. Antonowicz, Zagadnienie podmiotowości prawa międzynarodowego, „Annales UMCS” 1998, Vol. XLV, s. $7 \mathrm{in.}$ 
zycznej formuły jako „non - state actors”. ${ }^{146}$ Choć z nazwy wynika raczej politologiczny kontekst, $w$ istocie chodzi tu o podmioty prawa międzynarodowego inne niż państwa. Koncepcja jest ponadto otwarta na nowe kandydatury, także kontrowersyjne. Wydaje się, że odzwierciedla ona aktualny etap rozwoju teorii podmiotowości prawa międzynarodowego. ${ }^{147}$ Dawniej w tym obszarze bezdyskusyjnie dominowały państwa, które przecież zapoczątkowały i ukształtowały samo prawo międzynarodowe. To ostatnie czyniły najpierw intuicyjnie, stosownie do bieżących potrzeb, a więc $w$ ten sam sposób pośrednio formowały swą podmiotowość. Zwracając się do siebie wzajemnie, stopniowo tworzyły między sobą prawa i obowiązki. Innych form bytu (w relacjach poziomych) państwa początkowo nie uwzględniły normatywnie. Chociaż więc rzeczywistość nie do końca oznaczała „samotność państw” na forum międzynarodowym, to jednak formalnie tak to właśnie wyglądało. Co więcej - ów podmiotowy monopol trwał w zasadzie do czasów nowożytnych i współczesnych. Po części działo się tak siłą inercji, a częściowo wskutek braku zapotrzebowania na prawo międzynarodowe inne niż międzypaństwowe. Dawało to swoisty „klincz” w sferze podmiotowej prawa międzynarodowego: skoro dotąd składały się nań wyłącznie państwa, to tak pojmowano prawidłowość, a inne warianty byłyby tu odstępstwem. Rozumowanie to skutecznie hamowało rozwój podmiotowości prawa międzynarodowego, w ramach której nawet najbardziej oczywiste kandydatury pozapaństwowe traktowano w kategorii „wyjątków”. Zapewne z dorobku cywilistów czy administratywistów wywodzono zaś eklektyczne uzasadnienia owych „wyjątków”, na przykład formułę „ułomnej podmiotowości prawnej”. Nie wszyscy jednak ulegli tej stagnacji, a „wyjątki” pojawiały się coraz częściej. ${ }^{148} \mathrm{Z}$ drugiej strony, zaniepokojeni tym konserwatyści swój pogląd o bezwzględnej supremacji państw na płaszczyźnie prawa międzynarodowego wyrażać poczęli dobitniej. ${ }^{149}$

146 Na ten temat m.in.: A. Bianchi, The Fight for Inclusion: Non-State Actors and International Law, in: From Bilateralism to Community Interest: Essays in Honour of Bruno Simma, ed by U. Fastenrath and others, Oxford University Press, Oxford - New York 2012, p. 39 \& n.; A.-M. Le Gloannec, Non-State Actors in International Relations: The Case of Germany, Manchester 2007; J.E. Nijman, Non-state actors and the international rule of law: Revisiting the "realist theory” of international legal personality, Amsterdam Center for International Law Research Paper Series 2010; w doktrynie polskiej przede wszystkim B. Mielnik, Kształtowanie się pozapaństwowej podmiotowości w prawie międzynarodowym, Wrocław 2008.

147 Por. M. Perkowski, Kształtowanie się podmiotowości prawa międzynarodowego, [w:] Prawo międzynarodowe. Księga pamiątkowa prof. Renaty Szafarz, pod red. J. Menkesa, Warszawa 2007, s. 454 i n.

148 C. Berezowski, Les sujets non souverains du droit international, Paryż 1939; W. Sukiennicki, Podstawa obowiązywania prawa narodów. Studium prawnicze, Wilno-Warszawa 1929, s. 41; W. Warkałło, Czy jednostki są podmiotami prawa międzynarodowego?, „Rocznik Prawa i Ekonomii” 1932, t. 1, s. 45-72.

149 W dniu 5 września 1920 r. Międzynarodowy Komitet Prawników (F. Larmaude, M. Huber, G. Kaeckenbeeck), któremu Rada Ligi Narodów powierzyła zadanie przygotowania opinii doradczej w sprawie prawnych aspektów kwestii Wysp Alandzkich, stwierdził m.in., że: (...) w braku wyraźnych postanowień w traktatach międzynarodowych, prawo dysponowania terytorium narodowym jest zasadniczo atrybutem suwerenności każdego państwa. Pozytywne prawo międzynarodowe nie uznaje prawa grup narodowych jako takich, do oddzielenia się od państwa, którego część stanowią, poprzez proste wyrażenie życzenia, nie przyznaje go w większym stopniu aniżeli przyznaje ono innemu państwu prawa do domagania się takiego oddzielenia. Ogólnie mówiąc, przyznanie lub odmowa przyznania części swojej ludności prawa do określenia swego politycznego losu w drodze plebiscytu lub w inny sposób jest wyłącznie atrybutem suwerenności każdego państwa; The Aaland Islands Question, League of Nations, Official Journal, Specjal Supplement nr 3, October 1920. Report of the International Committee of Jurists entrust by the Council of the League of Nations with the task of giving an advisory opinion upon the legal 
W mojej ocenie sytuację w zakresie otwarcia państwowej dotąd podmiotowości prawnomiędzynarodowej na podmioty spoza kręgu państw uporządkowała ,rewolucyjna” opinia doradcza Międzynarodowego Trybunału Sprawiedliwości w sprawie Reparacji, kończąc „erę samotnych państw” w międzynarodowym obrocie prawnym. ${ }^{150}$ Choć - wskutek opinii doradczej MTS w sprawie Reparacji z 1949 r. przewrót się ostatecznie dokonał - początkowo nie wydawał się zapowiedzią wielkich następstw. Zaakceptowana podmiotowość Organizacji Narodów Zjednoczonych, choć wyznaczała samoistną kategorię klasyfikacyjną w obrębie podmiotowości prawa międzynarodowego, to jednak opierała się - w gruncie rzeczy - na państwowym rdzeniu. Państwa po prostu odstępowały organizacjom międzynarodowym część płaszczyzny podmiotowej prawa międzynarodowego, cedując nań te kompetencje, które łatwiej - a przede wszystkim - skuteczniej realizuje się międzyrządowo. ${ }^{151} \mathrm{~W}$ ten sposób uformowała się koncepcja podmiotowości rządowych organizacji międzynarodowych, stanowiąc precedens w dotychczasowym monolicie, a także instrukcję dla przyszłej instytucjonalizacji. Organizacje międzynarodowe powstawały coraz liczniej, zwłaszcza w Europie, różniąc się między sobą nie tylko przedmiotem działalności (obok współpracy politycznej lub gospodarczej zajmować się miały współpracą wojskową czy problemami społecznymi), ale przede wszystkim zakresem przekazanych przez państwa kompetencji. Przykładowo - Radzie Europy przekazano kompetencję koordynacyjną, a z kolei wspólnoty europejskie - wyposażono w wiązkę kompetencji determinujących ich ponadnarodowy charakter, ${ }^{152}$ dzięki czemu wspólnoty, a następnie Unia Europejska, uzyskały możliwość bezpośredniego oddziaływania na sferę stosunków wewnątrzpaństwowych, ${ }^{153}$ zaś ich prawo uregulowało nie tylko zachowania państw członkowskich i instytucji wspólnotowych, lecz przenikło w stosunki krajowe członków Unii. ${ }^{154}$ Progresja horyzontalna i wertykalna organizacji międzynarodowych w praktyce stosunków międzynarodowych uczyniły zasadnym określenie współczesności jako zorganizowanych

aspects of the Aaland Island Question, cyt. za: J. Tyranowski, Integralność terytorialna, nienaruszalność granic i samostanowienie w prawie międzynarodowym, Warszawa - Poznań 1990, s. 187-188.

150 Opinia doradcza w sprawie odszkodowania za szkody poniesione w służbie ONZ, ICJ Reports 1949 , s. 187 i 189. Nieco bardziej powściągliwe stanowisko aniżeli większość składu MTS, wyraził ówczesny polski sędzia MTS Bohdan Winiarski, choć w zasadniczych kwestiach zgadzał się z sentencją. Szerzej na ten temat patrz: M. Perkowski, Podmiotowość prawa międzynarodowego współczesnego uniwersalizmu w złożonym modelu klasyfikacyjnym, Białystok 2008, s. 22.

151 Klasyczna definicja organizacji międzynarodowej rządowej w: W. Morawiecki, Organizacje międzynarodowe, Warszawa 1965, s. 31 i 32.

152 Na temat podziału kompetencji patrz: P. Saganek, Podział kompetencji pomiędzy Wspólnoty Europejskie a państwa członkowskie, Warszawa 2002. Według Jana Barcza - powstającą w ten sposób strukturę można nazwać organizacją ponadnarodową, gdyż charakteryzuje się ona samodzielnym porządkiem prawnym, wykazującym oryginalność i efektywność. Według tego autora - mamy tu do czynienia z fenomenem nienależącym ani do prawa międzynarodowego, ani do prawa krajowego, lecz tworzącym trzeci, szczególny i samodzielny porządek prawny. Istnieją różnice w obowiązywaniu takiego prawa (np. prawa UE) względem prawa „zwykłej” organizacji międzyrządowej (np. ONZ czy Rady Europy). J. Barcz, Organizacja ponadnarodowa, „Sprawy Międzynarodowe” 1991, nr 7-8, s. 94.

153 NV Algemene Transport en Expeditie Onderneming van Gend en Loos v. Administratie der Belastingen, Zb.Orz. 1963, s. 3.

154 C. Mik, Europejskie prawo wspólnotowe. Zagadnienia teorii i praktyki, t. 1, Warszawa 2000, s. 559. 
stosunków międzynarodowych. ${ }^{155} \mathrm{Z}$ kolei na forum organizacji międzynarodowych jednostki oraz zbiorowości ludzkie konsekwentnie zabiegały o samostanowienie, równouprawnienie i prawa człowieka, co skutkowało stopniowym przenikaniem podmiotów indywidualnych na grunt prawa międzynarodowego. ${ }^{156}$

Głównym obszarem tej swoistej ekspansji stała się prawnomiędzynarodowa ochrona praw człowieka, zarówno w jej wymiarze uniwersalnym, ${ }^{157}$ jak i regionalnym. ${ }^{158} \mathrm{~W}$ jej efekcie nadano jednostkom szeroki zakres praw i obowiązków. Przede wszystkim (jako odstępstwo od reguły) otwarto przed jednostką podwoje międzynarodowych instytucji sądowych i quasi-sądowych (Europejski Trybunał Praw Człowieka, Europejski Trybunał Sprawiedliwości, Komitet Praw Człowieka), ${ }^{159}$ oferując jej ważny atrybut międzynarodowej zdolności do czynności prawnych (składowa podmiotowości prawnomiędzynarodowej) w postaci międzynarodowej zdolności sądowej.

Z drugiej strony - po drugiej wojnie światowej społeczność międzynarodowa zwróciła bezpośrednią uwagę na tych, którzy prawa człowieka masowo naruszali. Sformowanie ad hoc dwóch sądów międzynarodowych (Międzynarodowego Trybunału Wojskowego w Norymberdze i Trybunału Wojskowego dla Dalekiego Wschodu w Tokio) oraz skuteczne osądzenie osób winnych zbrodni przeciwko pokojowi, zbrodni wojennych oraz zbrodni ludobójstwa uruchomiło (zasadniczo pozostającą wcześniej w sferze teorii) instytucję międzynarodowej odpowiedzialności karnej jednostek. ${ }^{160}$ Co prawda oba trybunały po zakończeniu ich misji rozwiązano, a długotrwały impas kodyfikacji zagadnienia odpowiedzialności międzynarodowej w Komisji Prawa Międzynarodowego ONZ zdawał się zapowiadać przedmiotową stagnację, ${ }^{161}$ jednak okrucieństwa wojen bałkańskich $\mathrm{z}$ lat dziewięćdziesiątych XX w. oraz współczesnych im konfliktów w Rwandzie i Sierra Leone przyczyniły się do powołania kolejnych trybunałów ad hoc i osądzenia winnych zbrodni między-

155 Por.: J. Menkes, A. Wasilkowski, Organizacje międzynarodowe. Wprowadzenie do systemu, Warszawa 2004, s. 220 i n. oraz idem, Organizacje międzynarodowe. Prawo instytucjonalne, Warszawa 2006, s. 136-160.

156 M. Perkowski, Podmiotowość prawa międzynarodowego..., op. cit., s. 25.

157 Prawa człowieka ujęto w Karcie Narodów Zjednoczonych dość ogólnie, zaś autentycznej wykładni jej postanowień doszukiwano się w Powszechnej Deklaracji Praw Człowieka z 1948 r. Nie wdając się w spory, co do słuszności tego rozumowania, można stwierdzić, że funkcjonalnie nie dało się wówczas dokonać jednej, uniwersalnej wykładni Karty Narodów Zjednoczonych w zakresie ochrony praw człowieka. Regulację uniwersalną przeprowadzono dopiero w 1966 r., przyjmując na forum Zgromadzenia Ogólnego ONZ dwa pakty - Międzynarodowy Pakt Praw Obywatelskich i Politycznych (wraz z protokołem fakultatywnym) oraz Międzynarodowy Pakt Praw Gospodarczych, Społecznych i Kulturalnych.

158 Prace nad przyjęciem i wdrożeniem stosownych regulacji regionalnych podejmowano w różnym czasie i zakresie. W Europie do dziś obowiązuje Europejska Konwencja Praw Człowieka i Podstawowych Wolności z 1950 r., do której później załączono system protokołów dodatkowych. Z kolei w Afryce regionalna regulacja pojawiła się dopiero po ponad trzydziestu latach (Afrykańska Karta Praw Człowieka i Ludów, Nairobi 1981 r.).

159 Patrz na ten temat: A. Łopatka, Międzynarodowe prawo praw człowieka. Zarys, Warszawa 1998, s. 172 i n.

160 M. Perkowski, Podmiotowość prawa międzynarodowego..., op. cit., s. 26.

161 Ewolucję zagadnienia międzynarodowej odpowiedzialności karnej osób fizycznych interesująco zaprezentował M. Flemming, Międzynarodowe sądownictwo karne. Nowe perspektywy, „Wojskowy Przegląd Prawniczy” 1994, $\mathrm{nr} 2$, s. 3 i n. 
narodowych. ${ }^{162}$ Kulminacją instytucjonalnego odrodzenia międzynarodowej odpowiedzialności karnej jednostek stało się utworzenie Międzynarodowego Trybunału Karnego, który nie tylko (podobnie jak trybunały ad hoc) wymusza podmiotowość prawnomiędzynarodową jednostek winnych szczególnych naruszeń prawa międzynarodowego, ${ }^{163}$ ale sam w sobie (jako międzynarodowa instytucja nie przypisana do organizacji międzynarodowej) stanowi interesującą formę podmiotowości prawnomiędzynarodowej. ${ }^{164}$

W stosunkach krajowych jednostki nie korzystają z naturalnej wyłączności podmiotowej i funkcjonalnie konstruują rozmaite twory organizacyjne, których podmiotowość ujmowana jest w kategorii „osoby prawne”. Te ostatnie zaś (podobnie jak osoby fizyczne, choć z innych na ogół względów) również podejmują ekspansję na forum międzynarodowe. ${ }^{165}$ Ich aktywność zwykle postępuje za aktywnością osób fizycznych - wszędzie tam, gdzie skala, upowszechnienie lub rutyna sprzyjają zorganizowanym formom podmiotowym, przede wszystkim w sferach: gospodarki, ${ }^{166}$ ochrony praw człowieka ${ }^{167}$ i ochrony środowiska. ${ }^{168}$ Warto dodać, że w ostatnich dziesięcioleciach na forum podmiotowym prawa międzynarodowego pojawiać się zaczęły rozmaite formy publiczno - prywatne, szczególnie tam, gdzie - z różnych względów - samodzielna działalność sektora prywatnego lub publicznego nie byłaby wystarczająco efektywna lub po prostu możliwa. ${ }^{169}$

Temat kształtowania się podmiotowości prawa międzynarodowego w kierunku rozwoju non-state actors jest niezwykle rozległy. Z drugiej strony - nieustannie po-

162 Były to: Międzynarodowy Trybunał Karny dla osądzenia sprawców naruszeń prawa humanitarnego w b. Jugosławii, Międzynarodowy Trybunał Karny dla Rwandy oraz Trybunał Specjalny dla Sierra Leone.

163 Na ten temat - patrz m.in.: M. Płachta, Jurysdykcja Międzynarodowego Trybunału Karnego, „Studia Prawnicze” 2002, nr 4, s. 5 i n.

164 Por.: P. Milik, Międzynarodowa osobowość prawna i zdolność prawna Międzynarodowego Trybunału Karnego, „Państwo i Prawo" 2003, nr 9, s. 68 i n.

165 Tematykę interesująco omawia: A. Heinemann, Business Enterprises in Public International Law: The Case for an International Code on Corporate Responsibility, in: From Bilateralism to Community Interest: Essays in Honour of Bruno Simma, ed by U. Fastenrath and others, Oxford University Press, Oxford - New York 2012, p. 718 \& n.; a w doktrynie polskiej: K. Karski, Osoba prawna prawa wewnętrznego... op. cit..

166 Patrz: E. Cziomer, L.W. Zyblikiewicz, Zarys współczesnych stosunków międzynarodowych, Warszawa - Kraków 2002, s. 80 i n.

167 Patrz: K. Karski, Osoba prawna prawa wewnętrznego jako podmiot występujący przed Europejskim Trybunałem Praw Człowieka, w: Ochrona praw człowieka w świetle prawa RP, pod red. S. Pikulskiego, Olsztyn 2002, s. 186 i n.; tenże, Problem statusu korporacji ponadnarodowych w prawie międzynarodowym (globalizacja a podmiotowość prawa międzynarodowego), w: Nauka prawa międzynarodowego u progu XXI wieku, pod red. E. Dyni, Rzeszów 2003, s. 123 i n.; tenże, Status osób prawnych na podstawie Protokołu Fakultatywnego do Międzynarodowego Paktu Praw Obywatelskich i Politycznych (uwagi de lege lata i de lege ferenda), „Zeszyty Naukowe WSHiP im. Ryszarda Łazarskiego w Warszawie" 2001, nr 5, s. 117 i n.

168 Patrz: E. Kośmicki, Problem ochrony środowiska w przedsiębiorstwach międzynarodowych, „Ekonomia i Środowisko" 2004, nr 2, s. 141 i n.

169 Interesujące rozważania zaprezentował w tu: K. Karski, Problem statusu korporacji ponadnarodowych w prawie międzynarodowym (globalizacja a podmiotowość prawa międzynarodowego), [w:] Nauka prawa międzynarodowego u progu XXI wieku, pod red. E. Dyni, Rzeszów 2003, s. 123 i n.; patrz także: E. Karska, Korporacje transnarodowe wobec międzynarodowego prawa humanitarnego, w: Korporacje transnarodowe. Jeden temat, różne spojrzenia, pod red. J. Menkesa i T. Gardockiej, Warszawa 2010, s. 151 i n.; M. Perkowski, Partnerstwo publiczno - prywatne w ujęciu międzynarodowym. Natura koncepcji, w: Partnerstwo publiczno-prywatne. Zagadnienia teorii i praktyki, pod red. tegoż, ze słowem wstępnym C. Kosikowskiego, Białystok 2007, s. 44 i n. 
jawiają się próby skorzystania z formuły podmiotowej państwa przez byty, które państwami, póki co, nie są. Tu krąg jest też bardzo szeroki. Długo z czołowych stron mediów masowych nie schodziło Kosowo, którego status stał się w pewnym momencie przedmiotem orzekania MTS. ${ }^{170} 22$ lipca 2010 r. Trybunał uznał, że deklaracja niepodległości Kosowa z 2008 roku nie narusza prawa międzynarodowego. ${ }^{171}$ Wyrok w nauce uznano za kontrowersyjny, ale przyczynił się on do szerszej akceptacji Kosowa jako państwa. ${ }^{172}$ Wydaje się, że pomimo wielu prób Rubikonu nie może wciąż przekroczyć Autonomia Palestyńska, która przecież przyjmuje postawę podmiotową i o swą podmiotowość prawnomiędzynarodową usilnie zabiega na forum Narodów Zjednoczonych, gdzie nastąpiło de facto jej uznanie (jako Palestyny) poprzez przyjęcie w poczet członków UNESCO, a z drugiej strony - wskutek zabiegów Izraela i USA - nie doszło do analogicznego posunięcia w ONZ. Co prawda Palestyna uzyskała 29 listopada 2012 roku status nieczłonkowskiego państwa obserwatora ONZ (zbliżony do pozycji prawnej Stolicy Apostolskiej w ONZ), jednak nie trudno zauważyć, że takie rozwiązanie nie tyle potwierdza właściwą kategoryzację Palestyny w ramach klasyfikacji podmiotowości prawa międzynarodowego, ile stanowi modus vivendi w skomplikowanej politycznie sytuacji. ${ }^{173}$ Równocześnie w stosunkach międzynarodowych pojawiają się co jakiś czas byty określane w nauce jako „reżimy terytorialne de facto”, jak choćby: Naddniestrze, Abchazja czy Osetia Południowa. Ich dążenia niepodległościowe nauka prawa międzynarodowego w znacznej mierze uznaje za bezpodstawne, co nie zmienia faktu, że są one dla państw i społeczności międzynarodowej realnym problemem do rozwiązania. ${ }^{174}$ Tym bardziej, że dążenia secesjonistyczne pojawiają się także w dumnych ze swej demokracji państwach członkowskich Unii Europejskiej: w Hiszpanii, Francji, Belgii, Holandii, Austrii czy we Włoszech. Oczywiście mamy tu do czynienia z bardzo zróżnicowanym zbiorem dążeń emancypacyjnych. W jednych krajach ruchy odśrodkowe dążą do pełnej suwerenności, a w innych oczekują tylko autonomii, dzięki której łatwiej

170 Por.: P. Czubik, Niepodległość Kosowa - niebezpieczeństwo dla Zjednoczonej Europy? Krótki zarys problemu, [w:] Bałkany u progu zjednoczonej Europy, pod red. tegoż, Kraków 2008, s. 129 i n.

171 Accordance with International Law of the Unilateral Declaration of Independence in Respect of Kosovo, ICJ Advisory Opinion 22, July 2010.

172 Por.: A. von Bogdandy and M. Jacob, The Judge as Law-Maker: Thoughts on Brono Simma's Declaration in the Kosovo Opinion, in: From Bilateralism to Community Interest: Essays in Honour of Bruno Simma, ed by U. Fastenrath and others, Oxford University Press, Oxford - New York 2012, p. 809 \& n.; P. Daranowski, Precedens Kosowa a przyszłość Bośni i Hercegowiny, www.grocjusz.edu.pl/Materials/pd_kosowo.pdf ; T. Fleiner, The Unilateral Secession of Kosovo as Precedent in International Law, in: From Bilateralism to Community Interest: Essays in Honour of Bruno Simma, ed by U. Fastenrath and others, Oxford University Press, Oxford - New York 2012, p. 877 \& n.; J. Frowein, Kosovo and Lotus, From Bilateralism to Community Interest: Essays in Honour of Bruno Simma, ed by U. Fastenrath and others, Oxford University Press, Oxford - New York 2012, p. 923 \& n.

173 Por.: M. Perkowski, Podmiotowość prawa międzynarodowego..., op. cit. Warta odnotowania jest podmiotowa postawa Palestyńczyków, którzy ustawiają się na forum międzynarodowym w roli państwa, niezależnie od przeciwności.

174 B. Janusz-Pawletta, Separatystyczne dążenia Naddniestrza, Abchazji i Osetii Południowej a prawo międzynarodowe, „Bezpieczeństwo Narodowe” 2006, nr 2, s. 95 i n. 
jest kultywować własny język i kulturę. ${ }^{175}$ Wydaje się, że najsilniejsze są secesjonizmy, które znajdują uzasadnienie w odrębności narodowo-etnicznej, ekonomii, dotychczasowej strukturze administracyjnej oraz w postawach społecznych. Aktualnie na forum międzynarodowym najbardziej zauważalne są hiszpańskie: Kraj Basków i Katalonia, a także postulowana w Północnych Włoszech Padania. Dyskutuje się także o dążeniach emancypacyjnych w obszarach belgijskich: Walonii, Flamandii i stołecznej Brukseli czy brytyjskich: Szkocji i Irlandii Północnej. Wydaje się, że - poza ewentualną stagnacją - rozważać tu można dwie ewentualności. Albo będzie kontynuowana „ścieżka emancypacyjna” w kierunku samodzielnego państwa, co jest „rozpoznanym”, ale trudnym wyzwaniem dla wszystkich: zainteresowanego regionu, państwa obejmującego ów region oraz społeczności międzynarodowej, albo nastąpi „nowe otwarcie społeczności międzynarodowej na regiony”, poprzez przyznanie im większego zakresu kompetencji na forum międzynarodowym, co nie dość, że nie jest łatwe, to w dodatku stanowi nowość. Powstaje pytanie, czy z perspektywy prawa międzynarodowego można tu mówić o innowacji?

Próba odpowiedzi na tak postawione pytanie wymaga podejścia interdyscyplinarnego, a także ,zejścia na grunt krajowy”. W obrębie nauk prawnych obok umacniania, a niekiedy wręcz „zamykania się” poszczególnych dyscyplin, występuje proces całkiem przeciwny - przenikania się, współzależności i - w konsekwencji - formowania się nowych obszarów badawczych. Oczywiście naukowy punkt wyjścia zwykle znajduje się w obrębie klasycznej dyscypliny z zakresu nauk prawnych, jednak liczne interakcje, zapożyczenia, transpozycje powodujące specyficzne ukierunkowanie określonego obszaru praktyki, determinują analizującą ją naukę i publicystykę do zmiany podejścia (by uniknąć metody „,prokrustowego łoża”). W ten sposób nauki prawne rozprzestrzeniają swe zaangażowanie na obszary dotąd przezeń pomijane (w myśl schematu: skoro nie należały do typowej właściwości którejś z klasycznych dyscyplin nauk prawnych, nie były widocznie dla prawników), zyskując interesujący (najczęściej w ogóle słabo dlań znany) obszar badawczy, a wtórnie zapewniając praktyce walory, jakie niesie prawo i jego instrumentarium.

Biorąc to pod uwagę, warto zainteresować się zagadnieniem z pogranicza prawa międzynarodowego publicznego oraz prawa administracyjnego, jakim jest status międzynarodowy polskiego samorządu wojewódzkiego. Znaczenie tego zagadnienia dodatkowo wzrasta w kontekście proponowanego przez Unię Europejską zwiększenia roli regionów (w tym oczywiście i polskich samorządów wojewódzkich) we wdrażaniu unijnej polityki spójności (chodzi zwłaszcza o interwencję funduszy europejskich) w latach 2014-2020. Uzyskuje się tu także punkt wyjścia do

175 Szeroko i bardzo interesująco problematykę zarysowano w tygodniku „Forum” z 2012 r., nr 19 (7-13 maja), gdzie na s. 10-15 pod zbiorczym tytułem Eurowojna secesyjna zamieszczono wybór tekstów z: „Telepolis” (18.04.2012) oraz: „The Guardian”, „El Pais”, „The Guardian”, „Le Monde”, „De Staandard”, „Le Soir”, „Le Libre Belgique”, „Die Welt”, „Hospodarske Noviny”. 
badania kolejnych obszarów, np. problematyki urzeczywistnienia koncepcji Europejskiego Ugrupowania Współpracy Terytorialnej, rozwoju paradyplomacji samorządowej, statusu międzynarodowych porozumień regionalnych i wielu innych. Poszukiwanie odpowiedzi na pytanie, czy polskie regiony/województwa są nowymi podmiotami prawa międzynarodowego lub aspirują do tej podmiotowości, wydaje się więc a priori niezwykle interesującym wyzwaniem, które autor podjął w przygotowywanej monografii, a zarysował w kolejnym opracowaniu, w ramach niniejszego numeru „Białostockich Studiów Prawniczych”. 


\section{THE CONCEPT OF “NON-STATE ACTORS” AND INTERNATIONALIZATION OF REGIONS}

In recent years, a significant change in the approach of international law scholars to the issue of legal personality can be noticed. In particular, it is manifested in the openness to the development of the legal persons' catalogue, as a result of the progress in practice through the second half of the 20th century to the beginning of this century. After the long supremacy of States, as subjects of international law, they have accepted, directly or indirectly, the legal personality of other categories of international relations actors. The International Court Of Justice Advisory Opinion of 11 April 1949 concerning Reparation for Injuries Suffered in the Service of the United Nations, appeared to be a breakthrough case, in which the Court somehow "unlocked" the concept of legal personality in international law for subjects other than States. Especially governmental international organizations benefited from it. Furthermore, the development of international human rights law and international criminal responsibility of individuals have contributed to the empowerment of individuals in international law. The process is not yet finished. Other applicants either obtain acceptance of international legal personality (such as legal persons: multinational corporations, NGOs, and others), or keep operating as actors aspiring to international legal personality (as it is noticed and analyzed in academic researches). Such subjects as Transnistria, Abkhazia and South Ossetia were internationally noted mainly due to separatisms and secessionist aspirations (and due to the almost universal lack of international recognition of independence proclaimed by them, they have been called "de facto regimes"). From the perspective of a Member State of the European Union, but also from the perspective of a Polish voivodship, the emancipatory aspirations submitted by the Spanish regions: the Basque Country and Catalonia, postulated by Padania in Northern Italy, in Belgium by the Walloon Region, the Flemish Region and the Brussels-Capital Region, and by British regions: Scotland and Northern Ireland, are interesting in scientific terms. The concept of "Non-State Actors" seems to justify the scientific study of the status of regions (for example, Polish voivodships) in international law and the prospects for its development in this area.

Keywords:

International legal personality, non-state actors, actors in international relations, internationalization of regions 